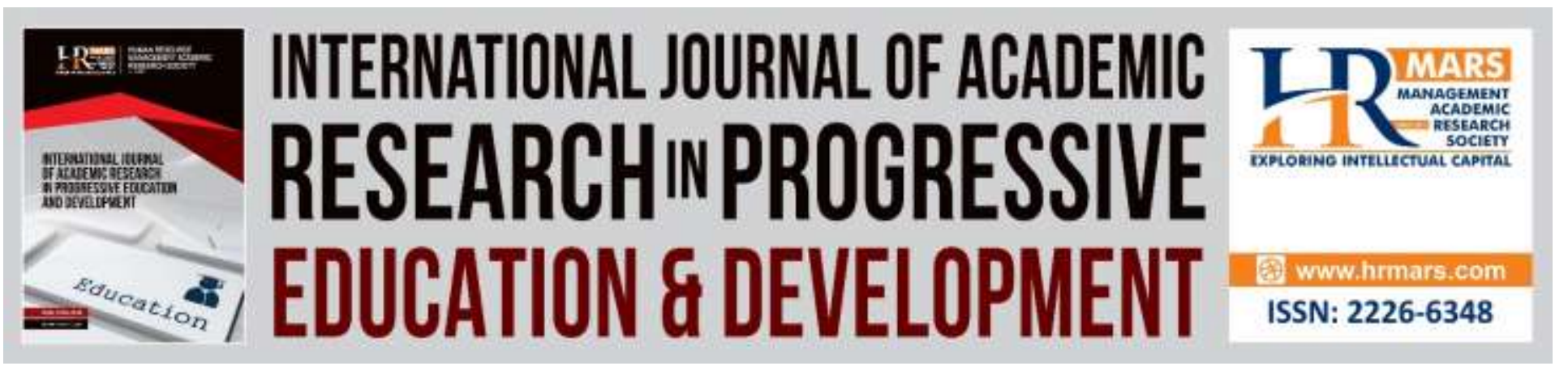

\title{
Students Course Experience: Reflections of Outcome- Based Education Implementation in Accounting Programmes in Higher Education
}

Rohaila Yusof, Khoo Yin Yin, Anis Suriati Ahmad, Hazianti Halim, Norlia Mat Norwani

To Link this Article: http://dx.doi.org/10.6007/IJARPED/v8-i2/5726

DOI: $10.6007 /$ IJARPED/v8-i2/5726

Received: 18 March 2019, Revised: 27 April 2019, Accepted: 19 May 2019

Published Online: 22 May 2019

In-Text Citation: (Yusof, Yin, Ahmad, Halim, \& Norwani, 2019)

To Cite this Article: Yusof, R., Yin, K. Y., Ahmad, A. S., Halim, H., \& Norwani, N. M. (2019). Students Course Experience: Reflections of Outcome- Based Education Implementation in Accounting Programmes in Higher Education. International Journal of Academic Research in Progressive Education and Development, 8(2), 228-238.

\section{Copyright: (c) 2019 The Author(s)}

Published by Human Resource Management Academic Research Society (www.hrmars.com)

This article is published under the Creative Commons Attribution (CC BY 4.0) license. Anyone may reproduce, distribute, translate and create derivative works of this article (for both commercial and non-commercial purposes), subject to full attribution to the original publication and authors. The full terms of this license may be seen

at: http://creativecommons.org/licences/by/4.0/legalcode

Vol. 8(2) 2019, Pg. 228 - 238

Full Terms \& Conditions of access and use can be found at http://hrmars.com/index.php/pages/detail/publication-ethics 


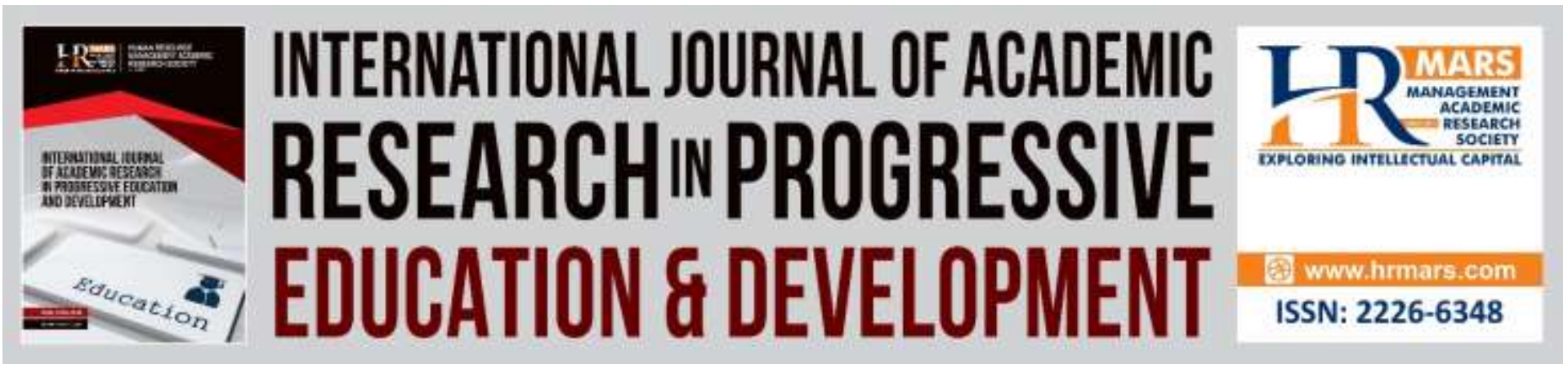

\title{
Students Course Experience: Reflections of Outcome- Based Education Implementation in Accounting Programmes in Higher Education
}

\author{
Rohaila Yusof \\ Universiti Pendidikan Sultan Idris, Malaysia \\ Email: rohaila@fpe.upsi.edu.my \\ Khoo Yin Yin \\ Universiti Pendidikan Sultan Idris, Malaysia \\ Email:khoo@fpe.upsi.edu.my \\ Anis Suriati Ahmad \\ Universiti Pendidikan Sultan Idris, Malaysia \\ Email: anissuriati@fpe.upsi.edu.my \\ Hazianti Halim \\ Universiti Pendidikan Sultan Idris, Malaysia \\ Email: hazianti@fpe.upsi.edu.my \\ Norlia Mat Norwani \\ Universiti Pendidikan Sultan Idris, Malaysia \\ Email:norlia@fpe.upsi.edu.my
}

\begin{abstract}
The purpose of the study is to analyse the level of implementation of four (4) principles of OBE; design down, clarity of focus, extended opportunity and high expectations in the courses offered in Accounting Degree Programme. The implementation level is assessed through students experience in major accounting courses by modification of Students Course Experience (SCE) questionnaire. 148 accounting degree students from three (3) HEs are the samples for this study. Students' achievement in Programme Outcomes (PO) is measured by categorizing the outcomes into two (2) categories of skills, Accounting Disciplinary Skills and Practical Competence. Students' achievement in Accounting Programme Outcomes is measured to examine students' achievement under OBE curriculum design. Responses on students' achievement are provided by two sides of
\end{abstract}


stakeholders, the students and educators. Main findings indicate that the four principles of OBE is implemented at moderately high level in the range of $3.35-3.50$ out of the scale of 5.0. The mean for the whole course experience is between 3.45 and 3.73. Findings on students' achievement of Programme Learning Outcomes (PLO) shows a higher score for Accounting Disciplinary Skills (ADS) compared to Practical Competence (PC) at 3.71 and 3.62 respectively. Students' responses is found to be at slightly higher mean compared to educators for both category of skills at a moderately high level. There is a significant correlation between OBE implementation level and ADS but not PC as reported by students. There is a significant correlation between ADS and PC. The findings imply that $O B E$ implementation needs to be improved by providing a more meaningful experience to students through multiple instructional and assessment strategies. Each student should be given opportunity to perform by allowing adequate time and support for them to reach their potential. Active involvement of industry partners will create clearer path between market demands and curriculum design.

Keywords: Outcome-based Education, Accounting Programme Outcomes, Learning Outcomes.

\section{Introduction}

The latest issues surrounding the multicultural, and multiracial context of Malaysian higher education address students experience enhancement, university governance, learning communities and globalization to name a few. The examination of these categories of data by Ghasemy, Hussin, Daud, Nor, Ghavifekr and Kenayathulla (2018) resulted in the classification of them into five major categories namely academic core activities, change and leadership, management, relationships, and work values. The first category, academic core activities emphasises more on students' outcomes and graduates employability. University performance in research and publications as measured on the world ranking system has always been the major Key Performance Indicator for university. Competitive graduates defined by new graduate aspirations is to become balanced and holistic individuals with entrepreneurship and other positive values. Training the next generation of leaders is a challenge for $\mathrm{HE}$, preparing graduates who are equipped with the skills of the $21^{\text {st }}$ century. Five major trends which are changing are the digital technologies, access to information, globalization, equity and accountability (Kilbane \& Milman, 2014). Development of these attributes needs a future focused curriculum. It goes back to the basic of ensuring the students get the best experience in their academic years through whatever a university can best offer them such as good teaching, competitive assessments, well developed skills, good support system and others. A study by Alfan and Othman (2015) shows that the demographic profile, entry qualifications and knowledge prior to entering the university such as economics, mathematics and accounting is crucial in assisting the students in undertaking the courses in both business and accounting programme. The forecasted growth in the other National Key Economic Areas demand a transformation in financial and management areas. Thus, education of future workforce in financial and business support services need to be upgraded to identify the strength and weaknesses and provide a platform for proper intervention. Graduates unemployment is an ongoing issue facing us. It has become a main agenda of the nation as government allocates more than RM20 million annually to train graduates to enhance their employability. Tracer studies done by MOHE in 2013, indicates only $47.6 \%$ of graduates are employed upon the convocation ceremony. Quality of graduates have been widely researched and 
debated. Finding of past researches on employers feedback for various discipline areas are consistent. Skills which need improvement among graduates are communications and language, critical thinking, problem solving and decision making, and knowledge in current issues local and global (Shafie, Mazlina \& Mohyin, 2014), ability to apply knowledge and concept in workplace and diversity awareness skills. HEls are being criticized for not preparing graduates with the right skills and work ready. Graduates employability is one the measurement items in the Key Performance Indicators (KPI) to be achieved by HEls. Graduate employability is to a certain extend a reflection of the effectiveness curriculum implementation of HEls, besides other environmental factors.

\section{Literature Review}

Past researches on employers' feedback share the same implications; to review and improve curriculum with more emphasis on the weaker skills identified. The issues identified are; existence of expectation gap towards the quality of accounting graduates in Malaysia, lacking of industry expert and practitioner in $T \& L$ of accounting at university level, to improve T\&L quality in accounting by improving accounting teachers' professionalism and finally to improve effectiveness of T\&L towards students centered learning (Accounting Roadmap 3).

The Accounting Roadmap 3 identify 12 Programme Learning Outcomes (PLOs) as standards to be achieved by accounting graduates (Table 1.1). The first six skills is referred to as Accounting Disciplinary Skills and Knowledge which is skills related to mastery and application of the content knowledge. The next 6 skills is categorized as Practical Competence a similar concept of work skills, generic skills and soft skills. 
INTERNATIONAL JOURNAL OF ACADEMIC RESEARCH IN PROGRESSIVE EDUCATION AND DEVELOPMENT

Vol. 8, No. 2, 2019, E-ISSN: 2226-6348 @ 2019 HRMARS

Table 1.1: Programme Learning Outcomes the Measure of Achievement in Accounting

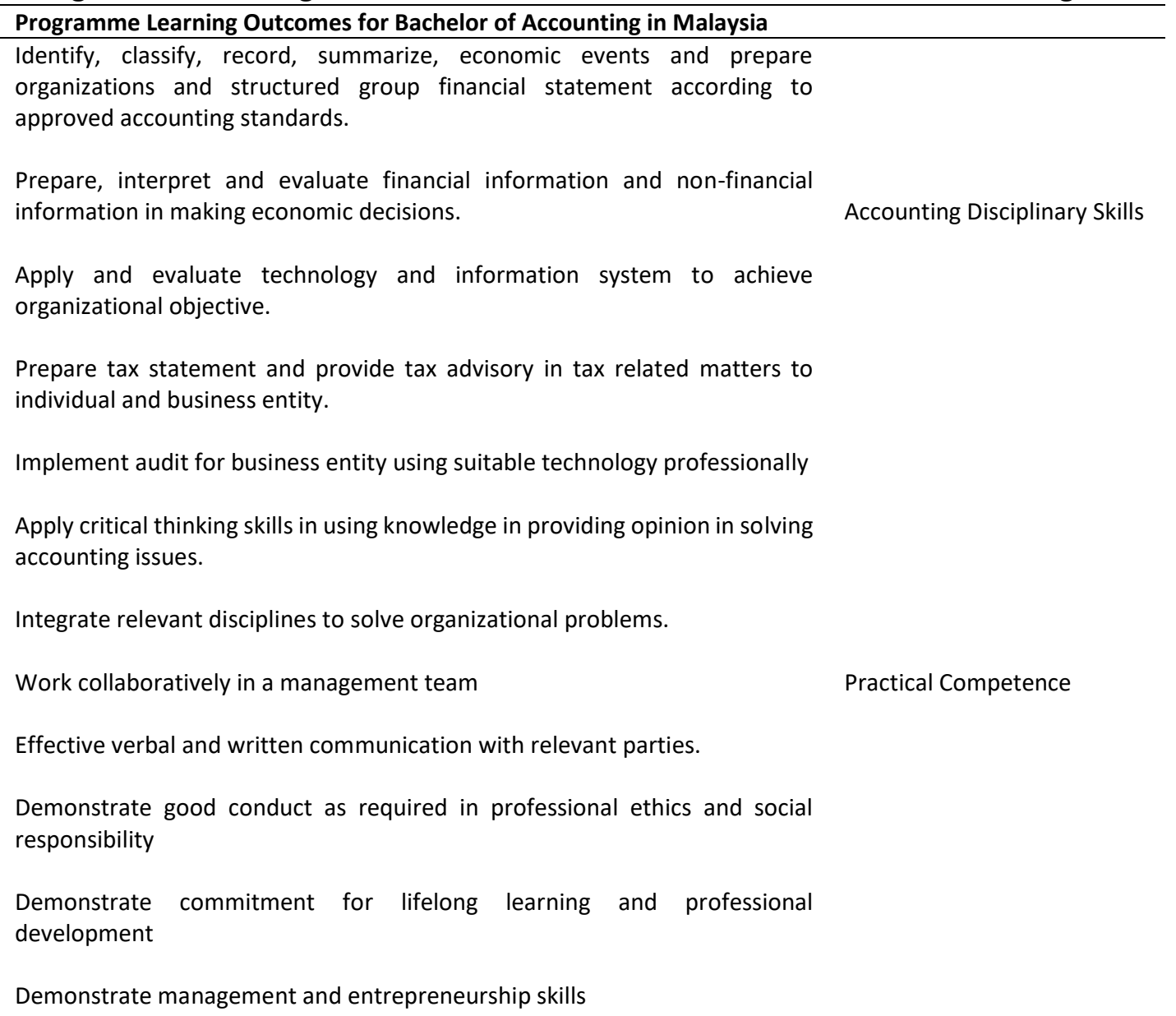

The evolution of OBE as discussed in (Biggs \& Tang 2007), comes in three distinct versions; the earlier intention of OBE by Spady (1994) introduced to a group of disadvantages students not able to follow the standard disciplines, he set up realistic targets for them to achieve including general humanistic values; second stage of OBE is designed for quality compliance, more market and management oriented known better as accreditation which is assessed at institutional level (Ewell 1984; Miller and Ewell, 2005). The outcomes at these level are grouped under knowledge, skills, values or graduate attributes; the third version is outcome based teaching and learning (OBTL) which originates in the Dearing Report (1997) which outcomes are designed to enhance teaching and assessment, which translate to how well students have learned what is intended they should learn. It does not refer to the list of content to be covered in certain time. OBTL has three essential features; state the intended outcomes of the course, tailored or align teaching to increase the outcomes achievement and lastly to assess the achievement of outcomes. Constructive alignment is the term used by Biggs which means systematically aligning the T\&L activities, assessment tasks and intended learning outcomes. This is in line with the classic Bloom Taxonomy which classify outcomes in three different forms; cognitive, affective and psychomotor and the outcome achievement at various levels. 


\section{Methodology}

The objectives of this study are to identify the level of implementation of OBE in the courses offered and how it relates to students experience in the courses they attend and the academic environment. Students' achievement in Accounting Programme Outcomes is assessed to examine students' achievement under OBE curriculum design. This identification is done through analysing the relationship between the four principles of OBE; design down, clarity of focus, high expectation and expanded opportunity and students' course experience;

1. What is the level of implementation of OBE at Institutional level according to the OBE principles?

1.1 Level of DD, CF, EO and HE

1.2 Level of implementation of design down (learning resources, learning community, student support)

2. What is the level of students' achievement in Accounting Disciplinary Skills and Practical Competence under OBE curriculum design?

3. Correlation between OBE implementation, Accounting Disciplinary Skills and Practical Competence.

4. Correlation between the four principles design down, clarity of focus, high expectation, expanded opportunity

This study uses quantitative method design, using questionnaires as the instrument. Respondents consists of 200 final year accounting students from three (3) Higher Education Institutions (HEIs). HE students in Accounting Programmes undergraduate programme is the population of this study. Respondents for this study is divided into 2 groups: First group is 200 undergraduates accounting programme students from 3 universities. 74\% of the questionnaires is returned, equivalent to 148 respondents. Second group is 32 respondents consist of educators who provide response for students' achievement of accounting programme outcomes. Outcomes is categorized into two (2) categories of skills: Accounting Disciplinary Skills and Practical Competence. Data from questionnaire is analysed using SPSS. This study uses a modified Course Experience Questionnaire (CEQ) to gather perceptions of recent graduates about the quality and usefulness of their programs. The original CEQ consists of 25 coded items i.e. statements to which respondents are asked to state a level of agreement or disagreement. Each item in this Questionnaire has the response alternatives of 5 degrees of agreement; Strongly Agree, Agree, Partially, Disagree and Strongly Disagree.

\section{Findings}

The implementation level of principles of OBE as practiced in the HE. The four principles are; Design Down, Clarity of Focus, Expanded Opportunity and High Expectation. The first principle of outcomebased education is expanded opportunity, by which intellectual quality is not something reserved for a few learners: it is something that should be expected of all learners (Killen, 2000). This discourages educators from generalizing manifestations of learned behaviour from students, considering that every student is a unique learner, and thus granting an expanded opportunity to 
students in the process of learning and more importantly in assessing their performance (Macayan, 2017). Killen (2000) insinuates that in order to have the clarity of focus, everything teachers do must be clearly focused on what they want learners to ultimately be able to do successfully. This is in line with the statement by Macayan (2017) who stressed that educators should be made aware and conscious about the outcomes of education each student must manifest or demonstrate at the course level and that these outcomes at the classroom level are connected to the attainment of higher level outcomes. In general the overall mean score for Outcome Based Experience principles is moderately high $(M=3.42)$. The highest mean score is clarity of focus at 3.50 while the lowest mean score is expanded opportunity.

Table 1.2: Overall Mean Score, Standard Deviation and Level for Outcome Based Experience Principles

\begin{tabular}{llll}
\hline $\begin{array}{l}\text { Outcome } \\
\text { Experience Principles }\end{array}$ & Mean & Standard Deviation & Level \\
\hline Expanded Opportunity & 3.35 & .589 & Moderately High \\
Clarity of Focus & 3.50 & .458 & Moderately High \\
Design Down & 3.41 & .420 & Moderately High \\
High Expectation & 3.45 & .474 & Moderately High \\
TOTAL & $\mathbf{3 . 4 2}$ & .436 & Moderately High \\
\hline
\end{tabular}

Next question is on the level of students' achievement in Accounting Disciplinary Skills and Practical Competence under OBE curriculum design. In terms of the accounting curriculum, there is a move away from mastery of formulas and procedures to an understanding of the interpretation of financial information which has necessitated changes in the way the subject is taught and assessed (Ngwenya, 2014). A study by Akir, Eng and Malie (2012) indicated that there is a significant difference in the mean grade point average between OBE students with aided technology learning in comparison to non-OBE students by which the mean grade point average for OBE cohorts is significantly higher than mean grade point average for non-OBE cohorts. 12 programme outcomes are listed for respondents to assess their achievement in the final year of their studies. The first six of the programme outcomes (outcomes 1-6) is categorized as accounting disciplinary skills and the next six outcomes as practical competence skills (outcomes 7-12). Students' self-assessment has shown that the students rate their achievement in disciplinary skills higher than the educators with the mean of 3.71 and 3.60 respectively. This is supported by Ghazali et al., (2008), where the highest score is on providing knowledge to students, while the least achievable learning outcome was managerial and entrepreneurial skills. As for practical competence the mean for students and educators response are in the same range, 3.69 and 3.67 respectively. Both category of skills are rated at a moderately high mean by both groups. This shows that the achievement of programme outcomes under the OBE curriculum design is moving towards positive achievement. Considering the respondents are in their final year there is still a lot to be done in their stay before graduation. The findings is supported by Ruhanita, Zakiah, Rosiati and Aini (2014) who found that the mean score among the students tend to be higher than the university and employers on students' 
achievement after internship programme, which is more obvious for the Accounting Disciplinary Skills.

Table 1.3: Students Achievement of Accounting Programme Outcomes

\begin{tabular}{|c|c|c|c|c|c|}
\hline & \multirow{2}{*}{$\begin{array}{l}\text { Accounting Programme Learning Outcomes } \\
\text { Accounting Disciplinary Skills (ADS) }\end{array}$} & \multicolumn{2}{|c|}{ Students response } & \multicolumn{2}{|c|}{ Educators response } \\
\hline & & Mean & sd & Mean & sd \\
\hline 1 & $\begin{array}{l}\text { Identify, Classify, record, summarize, } \\
\text { economic events and prepare organizations } \\
\text { and structured group financial statement } \\
\text { according to approved accounting standards. }\end{array}$ & 4.01 & .43 & 3.91 & .56 \\
\hline 2 & $\begin{array}{l}\text { Prepare, interpret and evaluate financial } \\
\text { information and non-financial information in } \\
\text { making economic decisions. }\end{array}$ & 4.03 & .39 & 3.82 & .42 \\
\hline 3 & $\begin{array}{l}\text { Apply and evaluate technology and } \\
\text { information system to achieve organizational } \\
\text { objective. }\end{array}$ & 3.61 & .47 & 3.51 & .87 \\
\hline 4 & $\begin{array}{l}\text { Prepare tax statement and provide tax } \\
\text { advisory in tax related matters to individual } \\
\text { and business entity. }\end{array}$ & 3.69 & .89 & 3.60 & .76 \\
\hline 5 & $\begin{array}{l}\text { Implement audit for business entity using } \\
\text { suitable technology professionally }\end{array}$ & 3.55 & .73 & 3.49 & .85 \\
\hline \multirow[t]{3}{*}{6} & $\begin{array}{l}\text { Apply critical thinking skills in using knowledge } \\
\text { in providing opinion in solving accounting } \\
\text { issues. }\end{array}$ & 3.42 & .56 & 3.32 & .32 \\
\hline & Total Mean for ADS & 3.71 & .67 & 3.60 & .74 \\
\hline & Practical Competence & & & & \\
\hline 7 & $\begin{array}{l}\text { Integrate relevant disciplines to solve } \\
\text { organizational problems. }\end{array}$ & 3.53 & .78 & 3.46 & .46 \\
\hline 8 & Work collaboratively in a management team. & 4.02 & .34 & 3.89 & .78 \\
\hline 9 & $\begin{array}{l}\text { Effective verbal and written communication } \\
\text { with relevant parties. }\end{array}$ & 3.72 & .49 & 3.71 & .63 \\
\hline 10 & $\begin{array}{l}\text { Demonstrate good conduct as required in } \\
\text { professional ethics and social responsibility. }\end{array}$ & 3.98 & .51 & 3.91 & .77 \\
\hline 11 & $\begin{array}{l}\text { Demonstrate commitment for lifelong } \\
\text { learning and professional development. }\end{array}$ & 3.62 & .78 & 3.67 & .86 \\
\hline \multirow[t]{2}{*}{12} & $\begin{array}{l}\text { Demonstrate management and } \\
\text { entrepreneurship skills }\end{array}$ & 3.31 & .67 & 3.33 & .81 \\
\hline & Total Mean for Practical Competence & 3.69 & .63 & 3.67 & .78 \\
\hline
\end{tabular}

Correlation between OBE implementation, Accounting Disciplinary Skills and Practical Competence.

One of the many advantages of $\mathrm{OBE}$ is promoting the acquisition of specific skills and competencies in a country in which there are many skills shortages (Macatangay et. Al., 2016). The accounting disciplinary skills serve as the measure of ability of the students to perform several academic related tasks in terms of research projects, home works and as results of major and minor examinations. Meanwhile, a competency-based approach to qualification specifies expectations in 
terms of outcomes, or what an individual can accomplish, rather than in terms of an individual's knowledge or capabilities (Boritz \& Carnaghan, 2003). Correlation between OBE implementation according to the four principles and the achievement of Accounting Disciplinary Skills (ADS) and PC is tested. There is a significant correlation between OBE and ADS $(r=.0351), p<0.05$. However the correlation between OBE and PC is not significant, $p>.05$. The findings suggest that most effort done during courses contribute more to specific accounting disciplinary skills.

Table 1.4: Correlation between OBE, Accounting Disciplinary Skills and Practical Competence

\begin{tabular}{lllll}
\hline & Variables & OBE & ADS & PC \\
\hline OBE & $\mathrm{R}$ & 1 & .351 & .121 \\
& Sig (1 tailed) & & .029 & .089 \\
& $\mathrm{~N}$ & 148 & 148 & \\
\hline Accounting & $\mathrm{R}$ & .351 & & \\
Disciplinary & & & & \\
Skills (ADS) & & & \\
& $\mathrm{Sig}(1$ tailed) & .029 & & 148 \\
& $\mathrm{~N}$ & 148 & 148 & 1 \\
\hline Practical & $\mathrm{R}$ & .121 & .325 & \\
Competence & & & \\
& $\mathrm{Sig}(1$ tailed) & .089 & .031 & 148 \\
& $\mathrm{~N}$ & 148 & 148 & \\
\hline
\end{tabular}

\section{Discussion and Conclusion}

Overall the findings reveal that the level of implementation of OBE according to the four principles is at a moderately high level with a mean average of 3.46 out of scales of 5.0. All the four principles is being practiced at a fairly same level. 'Design Down' refers to consistency, systematically, coherently design down from significant culminating outcomes. In practice this principle is reflected in the support system such as library resources, course materials, use of technology in T\&L. IT facilities, welfare, academic advisory, counselling and facilities that encourage collaborative work. The lowest score is the on the relevance and latest course materials (3.38) and the highest is the usage of technology in T\&L. The findings support the implementation of the principle of design down in the implementation, at a moderate level. The flow of curriculum comes from the broader outcomes to the specific and assessment is integrated in a coherent manner at a moderate level. Clarity of focus is at 3.5 moderately high, the highest is on developing teamwork skills at 3.76 and the lowest is 3.15 'no excellent grades without content mastery'. The third principle 'Expanded Opportunity', with the highest on 'T\&LAs are interesting and attract students' attention at 3.54 and the lowest is on 'variations in T\&LAs help me to develop interest in the course. The fourth principle, 'high expectation' with the mean of 3.41. These findings show that the implementation of the four principles is still at an average level considering the initiative of curriculum change has started in 2004 and implemented by all academic programmes since 2008. It is an indication that the four principles is practiced at a moderate level not to the full extend. The findings is supported by studies on OBE implementation by Albert Chan (2009) who finds mechanical process of pursuing outcomes without deliberate revision of pedagogy, attitudes and assessment strategies fails to attain the continuous improvement concept that OBE implies. The achievement of accounting 
disciplinary skills and practical skills through accounting courses is rated at the same level by students and educators. It shows a kind of agreement between educators' expectations and students' perception of their capacity in accounting skills. In conclusion, the implementation of OBE in accounting programmes indicates the students experience of the four concepts of OBE in accounting courses. It shows that students are clear of the educators' expectations and clarity of focus in the delivery and assessment of accounting courses. Accounting as a discipline highly related to business and corporate world, is expected to produce graduates who are capable of using the technical and disciplinary skills for effective decision making and demonstrate a high level of practical competence.

\section{Acknowledgement}

This study was supported by UPSI internal educational grant (GPU khas) 2017-0255-107-01.

\section{References}

Akir, O., Eng, T. H., \& Malie, S. (2012). Teaching and learning enhancement through outcome-based education structure and technology e-learning support. Procedia - Social and Behavioral Sciences, Vol. 62, Iss. 24, Pg $87-92$

Alfan, E. \& Othman, M. N. (2005). Undergraduate students' performance; the case of university Malaya. Quality Assurance in Education, Vol. 13, Iss. 4, pp. 329 -343

Biggs, J. \& Tang, C. (2007). Teaching for quality learning at university. (3 ${ }^{\text {rd }}$ Ed.) Mc Graw Hill: England.

Boritz, J. E. \& Carnaghan, C. A. (2003). Competency-based education and assessment for the accounting profession: a critical review. Canadian Accounting Perspectives, Vol. 2, Iss. 1, pp $1-107$

Dearing, R. (1997). National Committee of Inquiry into Higher Education (Dearing Report). Higher Education in the Learning Society, report of the National Committee. Norwich: HMSO

Ewell, P. T. (1984). The self-regarding Institution: Information for excellence. Boulder, CO: National Centre for Higher Education Management Systems.

Ghasemy, M., Hussin, S., Megat Daud, M. A. K., Nor, M., Ghavifekr, S. \& Kenayathulla, H. B. (2018). Issues in Malaysian higher education: a quantitative representation of the top five priorities, values, challenges and solutions from the viewpoints of academic leaders. SAGE Open.

Kilbane, C., R. \& Milman, B. (2014). Teaching Models: Designing Instruction for the $21^{\text {st }}$ Century Learners. Pearson Education Inc.: New Jersey.

Killen, R. (2000) Standards-referenced assessment: linking outcomes, assessment and reporting. Keynote address at the Annual Conference of the Association for the Study of Evaluation in Education in Southern Africa, Port Elizabeth, South Africa, 26-29 September.

Macayan, J. (2017). Implementing Outcome-based education (OBE) framework: implications for assessment of students' performance. Educational Measurement and Evaluation Review, Vol. 8, Iss. 1

Macatangay, A. O., Braza, L. D., Gamboa, M. N., Gonzales, A. D., Fuentes, R. A., Macalalad, J. A., Hernandez, K. T., Montejo, J. R. \& Mendoza, F. M. (2016). Status of implementation and usefulness of outcomes-based education in customs administration program of one Asian university. Asia Pacific Journal of Education, Arts and Sciences, Vo. 3, Iss. 3, pp $62-69$ 
Miller, M. A. \& Ewell, P.T. (2005). Measuring upon college level learning. San Jose, CA: National Centre for Public Policy in Higher Education.

Ngwenya, J. C. (2014). Accounting teachers' understandings and practices of teaching and assessment in a context of curriculum change. Alternation, Vol. 21, Iss. 1, pp. 171-189.

Spady, W. G. (1994). Outcome Based Education: Critical Issues and Answers. ISBN-0-87652-183-9. Retrieved from http: www.files.eric.ed.gov on 17 October 2018. 